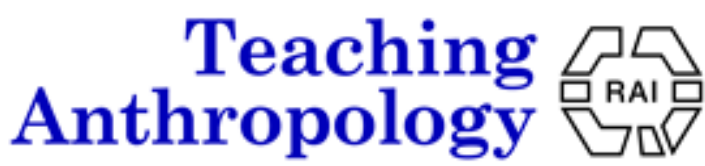

2021, Vol. 10, No. 4, pp. 17-35

\section{Subverting the white cis gaze: Toward a pedagogy of discomfort, accountability and care in the anthropology classroom}

\author{
Oda-Kange Midtvåge Dialloํ, Nico Miskow Friborg² \\ ${ }^{1}$ Norwegian University of Science and Technology, ${ }^{2}$ University of Stavanger
}

\begin{abstract}
We write from the starting point of teaching an anthropology course together consisting of predominantly white, middle class cis students. The course collaborated with a local NGO, and the students were given the task to study issues of discrimination and exclusion within youth, leisure activities. This gave us the opportunity to examine, and therefore challenge, what we and our students were taught in terms of 'the other', positionality and accountability in anthropological research. We share our journey of creating a norm-critical classroom, which was built on our counter-archive (Haritaworn, Moussa \& Ware, 2018) of anti-oppressive, queer, trans, BIPOC ${ }^{1}$ knowledge. We discuss how we made the students investigate their own positionalities and research interests, through our pedagogy of provoking discomfort by decentering whiteness and cisnormativity. We meditate on what it means to be teachers of anthropology that learn and work from differently marginalized positions within the Academic Industrial Complex (AIC). We honor the treasures we find in anti-oppression knowledge from the margins by joining a collective discussion on how to end epistemic violence within the classroom, the discipline and the broader AIC, while navigating the deeply colonial, cis- and heteronormative fabric of what is considered canon.
\end{abstract}

Keywords: Discomfort, Whiteness, Cisnormativity, Pedagogies of care, Counter-archiving.

"Do you want to erase the whole history of anthropology?!"

The statement was shouted at a group of students of ours in a presentation where they shared findings from a study on discrimination based on race, gender and sexuality in leisure activities for youth. The person shouting at the group of students is an anthropologist and was the representative of an NGO that we collaborated with as teachers on a course in applied anthropology at a Scandinavian university ${ }^{2}$. The students' comments that sparked this reaction were based on their recommendations for the NGO's approaches to research.

This article is a collaborative piece written from the starting point of this particular teaching experience, intertwined with snapshots of a work-in-progress zine on our critiques of anthropology and the Academic Industrial Complex $(\mathrm{AIC})^{3}$ and how we navigate working in and against it as a black queer person and a white queer nonbinary trans

\footnotetext{
${ }^{1}$ Black, Indigenous, People of Color.

2 To ensure anonymization in this article we do not further specify the country, university or NGO discussed here.

${ }^{3}$ We use the Academic Industrial Complex interchangeably with the Neoliberal Imperial University. For further explorations: Bacchetta et al. (2018), Harney \& Moten (2013), and Pearce (2020). For writings on the Nonprofit Industrial Complex:

Rodríguez (2007/2017), zeeninginlaos (2010) and Spade and Dector (2016).
} 
person, respectively. Our theorizing on and work in and against the AIC is shaped by our engagements with disability justice, anti-colonial, Black, queer and trans epistemologies that fight the colonial, white supremacist,

ableist, cis-heteronormative ${ }^{4}$ structures that govern universities as (well as other) state institutions. The decolonial, feminist collective Marronage (2019) reminds us, that colonialism is also a paradigmatic project and that the university as an institution is central to continuing the colonial project - including who has access ${ }^{5}$ (Bacchetta et al., 2018; Ohito, 2019; Kilomba, 2010; Harney \& Moten, 2013; hooks, 1989/2015). We understand anthropology as having a particularly central role in this both historically and today (Bolles, 2013; Wekker, 2016; Allen \& Jobson, 2016; Mullings, 2005; Essed, 1991). The anthropology department in question is certainly no exception to this rule, which is why we use this experience as an anchor for our analysis and intervention. We characterize our intervention as an act of counter-archiving, inspired by activist scholar and associate professor of sociology, Jin Haritaworn, scholar, educator and DJ, Ghaida Moussa and artist activist scholar, Syrus Marcus Ware (2018, p. 5), who explain that " $[t]$ o counter-archive [...] means to investigate the racial and colonial logics that shape "which subjects, objects, conducts, events and histories are heavily inscribed and remembered," and which are "forgotten, erased, or denied altogether."'. We frame our work as counter-archiving because we both reckon with canonized, extractivist anthropology and build up ethnographically based research and teaching that center and contribute to collaborative learning processes and social justice struggles. For us, counter-archiving then becomes an ongoing process of unlearning oppressive knowledge and self-learning abolitionist ${ }^{6}$ knowledge.

In the process of creating this piece we have experimented with different modes of writing and collective reflections, including a work-in-progress zine, presented in its full length here below and in snapshots throughout the article.

Zines are DIY self-published and self-circulated publications often created as booklets of drawings, images and texts bound by staples (Boatwright, 2019, p. 387). We chose the zine format because of the importance of zines, and other counter-archival materials like poetry, fiction and music, in the communities we organize in, where they offer a site for critique and dismantling of oppressive structures, for imagination and enactment of other ways of co-existing and as such function as transformative pedagogies (Boatwright, 2019, p. 392). Zines are not confined by the rules

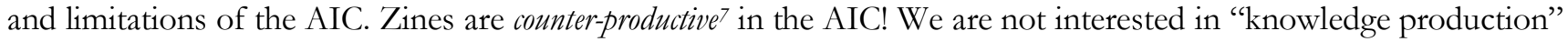
as a part of a capitalist chain of production (Levya Solano, 2019, p. 49). Instead, we believe in creating knowledge in, with and for communities and coalitions. By using our zine to structure the article we aim to let the style of zines spill into and "contaminate" the elitist, classist, high-theoretical writing conventions of the AIC. In this text we move between resisting and being stopped by the oppressive structures of the AIC and anthropology on one side and finding pockets within and around academia which offer moments of community, resistance and inspiration on the other side.

In the following, we reflect on our own training in sociocultural anthropology and our experiences with marginalization in the university. We share how we built up our counter-archive that offers a pedagogy which 1) invokes, stays with and analyzes discomfort, 2) expects, prepares for and transparently explores resistances to hurt and decentering in the classroom and 3) relies on a foundation of accountability and care.

\footnotetext{
4 We understand cisnormativity as the structures which assume everyone to be cis and which configure trans people as unintelligible, deviant, pathological and in need of correction. As an analytical concept, cisnormativity problematizes the normative category, the cis position (Spade, 2006; Linander et al., 2019). Cisnormativity is deeply interlinked with heteronormativity (Butler, 1990). When writing about the colonial, white supremacist, capitalist, ableist, cis-heteropatriarchy, we understand all these structures to be interconnected and inseparable, thus producing a system which devalues and configures especially women, queer and trans people who are Black, Indigenous, People of Color as disposable and killable (Lorde, 1984; hooks, 1989/2015; Lugones, 2010; Spade, 2011/2015; Raha, 2017).

5 While education, including university, is free in the Nordic countries, whiteness, class and cis-heteronormative structures create in/access to education.

${ }^{6}$ We use abolition in a broad sense, including abolition of slavery, racial capitalism, anti-blackness, coloniality, patriarchy, the gender binary, cis-heteronormativity, ableism and prison abolition. Abolitionist movements and knowledge not only work towards and focus on ending these structures but also on how to build "life-affirming institutions" (Gilmore, 2007; Bassichis, Lee \& Spade, 2011).

${ }^{7}$ Here we play on the double notion of counter-productive both as a critical act of countering oppressive structures, countercultural production and as in a refusal to produce and be productive within the AIC.
} 


\section{Where we write, research, teach and organize from}

I am Oda-Kange, and I am a Fulani-Norwegian, black, queer, cis person ${ }^{8}$, who is somewhere midway in my $\mathrm{PhD}$, in which I try to understand Afro-diasporic community building and blackness in Norway. Living in Tråante, Sapmie, I am continuously learning to navigate my position as a non-Indigenous person living on Sami territory ${ }^{9}$. As a doubleheritage black person with a middle-class background, I am one of a select few who has been privileged (and tokenized ${ }^{10}$ ) with a paid position to do research, and I therefore remind myself that many of the people in my communities, who I consider my colleagues and co-theorizers, are systematically excluded from academia. This process is sometimes lonely and emotionally tolling, why I am interested in resistance and care as methodologies in research-activism, teaching and relations with colleagues and friends. I am deeply concerned with creating knowledge collectively instead of in isolation in ways that counter the harmful colonial structures of most social science research.

I am Nico, and I am a white, queer, nonbinary trans person and activist scholar. My PhD project is on queer and trans activism, organizing and coalition-building against, beyond and on the margins of the Danish state and Nonprofit Industrial Complex from 1990 until today. Both my research and my teaching are deeply anchored in the community- and coalition-building that I am involved in and the questions and analyses which arise from this work. These are questions such as: How can I, as someone who navigates the AIC with race and class privileges while also being marginalized mainly due to anti-trans and anti-queer structures, redistribute and best use the access to time, resources, materials and spaces, that I am given through the AIC, in ways that benefit the world-making projects of the communities and coalitions I organize in? How can we create and widen spaces within the AIC where knowledge and demands from social justice struggles are critically engaged and taken seriously, and where those of us who work from/at the margins can build coalitions and resistances?

We are explicit about our experiences and situatedness because naming ourselves specifically as Fulani (African), black, queer and queer, nonbinary and trans, disrupts the illusion of the anthropological archetype and the violently white, cis-heteronormative, middle/upper class, Western space which the AIC actively works to uphold. When we name and situate ourselves, we claim space and we invoke discomfort because we question who can be present and visible and "who can speak" in the AIC (Kilomba, 2010; hooks, 1989/2015). At the same time, naming ourselves in this way is often ambiguous, as what and how we might name today can change tomorrow and will always be interpreted contextually. We theorize and navigate the AIC from experiences of being positioned as "bodies out of place” (Puwar, 2004; Abrahams, 2021), and “outsiders within” (Collins, 2000). While working from positions of marginality is painful, tiring and fuels us with anger it also opens possibilities. Inspired by queer, animal, critical race, and disability studies scholar Mel Chen (2012, p. 17), we "reside in this so-called negative zone, one of abjection, racial marking, toxic queerness, and illness, to think about the epistemic riches of possibility within. If this is not a recuperative project, it is nevertheless an affirmative one".

We write from the margins together. Working together in the AIC disrupts the forced individualism, competitive production pressure and career race. Our concern is not with helping the system survive or to continue its course (Jobson, 2021). Rather, we are interested in disobeying the rules of our discipline, and in exploiting the university's resources for the benefit of our communities as well as organizing outside the AIC. Working together is central to our survival and persistence within the AIC and is supportive of our pedagogy of accountability and care as we think critically together, continue to learn, hold space for vulnerability and share the burden of emotional labor.

\footnotetext{
8 A cis person is someone who is and/or identifies with the gender assigned at birth.

9 Sápmi/Sapmie has been colonized by Norway, Sweden and Finland for centuries, which is why I, as non-Indigenous Norwegian citizen, also occupy the status of settler.

10 Tokenization refers to the widespread AIC strategy to employ very few people with minority/marginalized status in order to cover a quota, often without much regard for genuine interaction with those people and their knowledge. Audre Lorde describes how being one of only two Black women invited to a feminist conference is an example of "[ $t$ ] he tools of a racist patriarchy [being] used to examine the fruits of that same patriarchy[.] It means that the only most narrow perimeters of change are possible and allowable," she states (Lorde, 1984, p. 111).
} 


\section{Creating a counter-archive}

As students we were introduced to anthropology as a noble discipline in which 'we' as Western observers of 'native' life and culture would provide theorization and analysis to a Western audience. We were taught that anthropologists are interpreters between worlds; "the West" and "the Rest", and that we had been gifted with the ability to put ourselves in their shoes and therefore to speak for those who could not speak. In this understanding and delivery of an anthropological canon, colonized, indigenous, racialized, queer and trans people were configured merely as objects of anthropological theorizing, never as knowledge-holders and theorizers. Some of the questions we asked ourselves as students, and sometimes dared to say out loud were: Where is the theorizing and historicizing on Nordic coloniality, such as the 'scientific' racism of Carl von Linné and Scandinavia's long history of colonization of Indigenous lands in Sapmi, Greenland, West Africa, India and the Caribbean? Why are we not analyzing the Nordic so-called universal welfare states' substantial economic foundation in slavery? ${ }^{11}$ Why are we reading all these travel diaries and fantastical renditions of 'native life' in the Pacific and Africa by white anthropologists who simultaneously loathe and lust for Indigenous people?

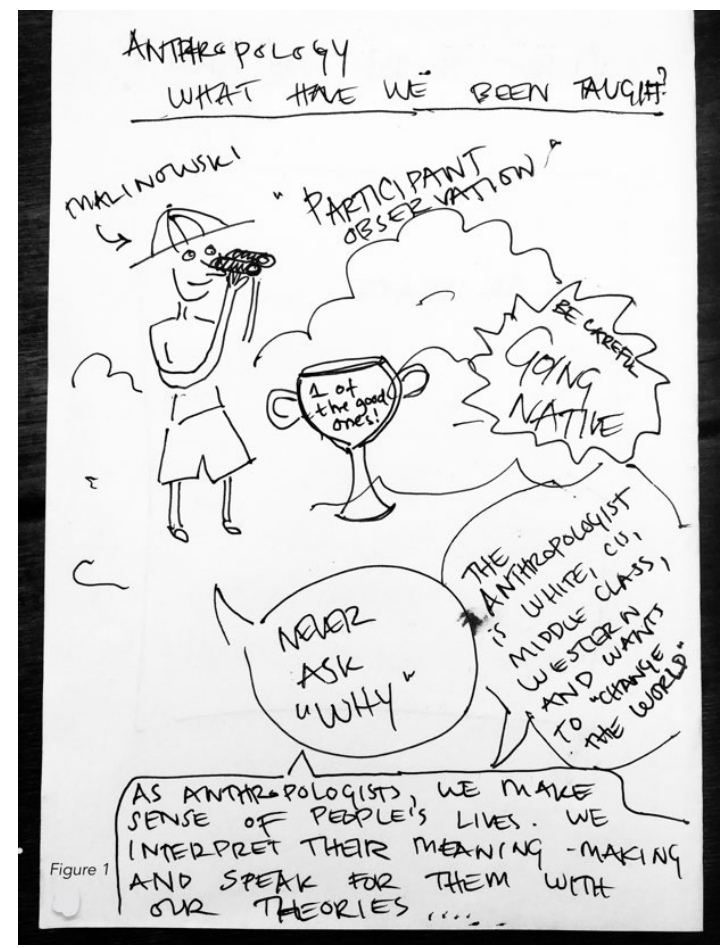

Why do we not critically dissect contemporary anti-Blackness and anti-Islam structures, such as the EU border regime, the incarceration of asylum seekers and ghetto laws ${ }^{12}$, and why are we not presented with tools to analyze whiteness as infrastructure and immune system (Bouteldja, 2016)? Why are we not challenging Nordic exceptionalism, femi- and homonationalism, gay imperialism and pathologization of transness? ${ }^{13}$ Why is gender never analyzed as a structure? And why is it always already binary and cisnormative? (Except the 'curious' gender and sexual practices of the Native Other ${ }^{14}$. Why did we not discuss how ignoring questions like these, not only within anthropology, leaves racist, colonial and cis-heteronormative logics unchallenged and thus bolstered?

Another central question we had to ask, was why the realities of people like us were always presented through the eyes of the white cis-hetero ableist observer, and almost never delivered by us in our own words and on our own terms. These questions guide our work and our processes of unlearning harmful, extractivist, canonized anthropology and self-learning abolitionist knowledge. Answering these questions requires leaving behind methodological tendencies to protect the un-knowable, unpositioned anthropologist, who wants to understand and do good by suffering marginalized Others and eventually 'give back' to them (TallBear, 2014).

${ }^{11}$ For work which unpacks this check out e.g.: Marronage (2017a, 2017b, 2017c, 2019), Jensen (2019).

12 We recommend reading: McIntosh (2014), Habel (2011), Sawyer \& Habel (2014), Arce \& Suárez-Krabbe (2018), Khalid (2020), Mendes (2020).

${ }^{13}$ For analyses of these questions check out: Sager and Mulinari (2018), Alm et al. (2021), Cohen (1997), Muñoz (1999), Manalansan (2018), El-Tayeb (2011), Haritaworn, Kuntsman and Posocco (2014), Johnson (2016), Puar (2007), Nebeling Petersen (2016), Stryker (1994), Spade (2011/2015), Raha (2017).

${ }^{14}$ For critiques of these tropes: Aizura et al. (2014), Towle and Morgan (2002). For work on gender and coloniality: Mohanty (1984) and Lugones (2010). 


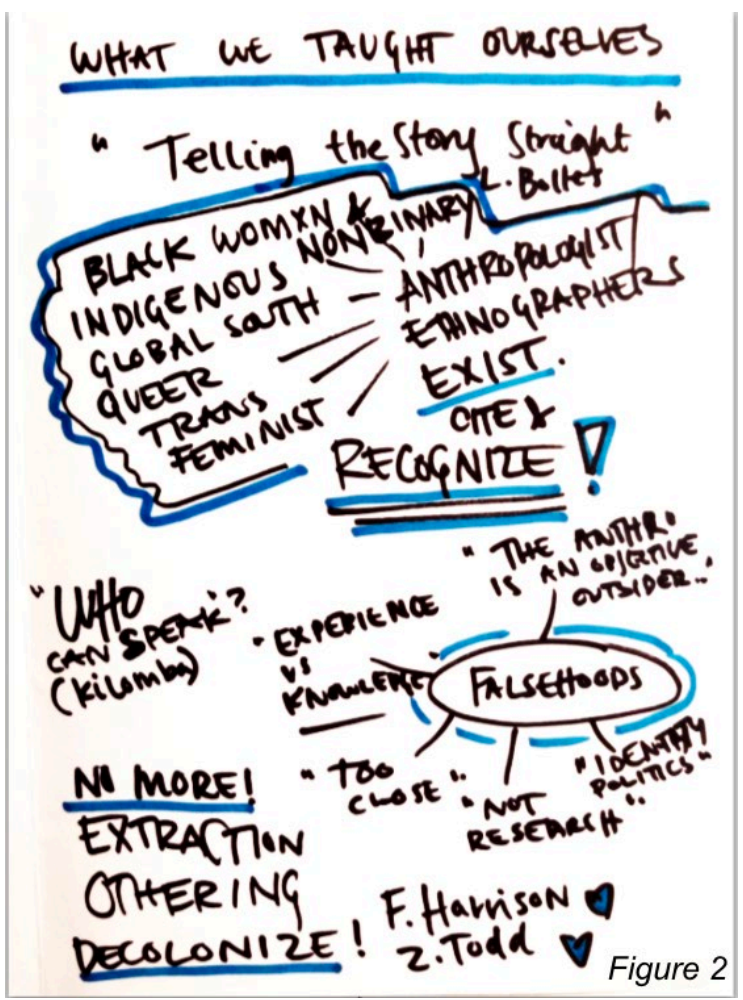

This anthropological trope creates objectivity regimes where situated knowledge from marginalized communities is rendered non-scientific and as mere experience, not theory (hooks, 1989/2015; Kilomba, 2010). We have been told by teachers, supervisors and co-workers: "this is not anthropology", "you are too close" (see figure 2). We felt the cost of 'not belonging', in the AIC through skepticism, silencing and sometimes direct rage. We understood that anthropology was not meant for us or for the people we engage in research alongside, but rather designed to keep us out. It was as if our presence and work was not only disrupting the peace and quiet of the dominating culture, but that it was an insult to the discipline itself. This institutional marginalization and epistemological resistance is disorienting, tiring and time-consuming. Navigating disorientation means that we at times have to do what is expected of us to avoid further resistance and violence and to try to assume control. Sometimes we persist and insist on being here (and being queer) and doing our work on our own terms. Either way, it always means that we have to do double work (Skadegård Thorsen, 2019) both in terms of unlearning and self-learning another canon as part of our counter-archive, as well as through the extra emotional labor that we disproportionately perform in the AIC (Bacchetta et al., 2018; Pearce, 2020). Various forms of emotional labor are constantly demanded from us by co-workers and students. In

addition, we navigate when to speak or stay silent, how to carefully choose our words to avoid being attacked or dismissed. On top of that we put work into our own survival within the AIC and otherwise (Pearce, 2020).

Instead of accepting these barriers, we began learning from activist scholars who work to further abolitionist movements and theorize from lived experience. (T)here we found concrete tools for collaborative knowledge creation and for doing research with, instead of research on (Jourian \& Nicolazzo, 2017), the communities we organize, resist and breathe in and from. ( $\mathrm{T}$ )here we learned to navigate epistemological resistance and the constant critiques of missing "objectivity" and "validity" of our work. The knowledge we self-learned (t)here prompts researchers to engage transparently and honestly and to question who is this knowledge for and who am I to do this? Such considerations include asking whether one should do this research at all (Tuck \& Yang, 2014; Simpson, 2007).

Alongside this, we continuously build on our guiding principles of creating knowledge which is accessible, community-based, collaborative, useful and accountable to our communities as well as to students/teachers/activists, and which causes as little harm as possible. We find that the classroom is a meaningful place to start this liberatory process. We acknowledge that the work we present in this text has been developed in a specific context, namely a predominantly white, cis classroom in Scandinavia. However, we hope that our sharing of tools and reflections on our processes of (un)learning can be useful to "teachers-educators-researchers-activists within learning communities" (Icaza \& de Jong, 2019, p. xxx) globally as well as beyond the confinements of the AIC.

In the next part, we will discuss precisely how we have used our classroom for countering oppressive and colonial ideas about what qualifies as (anthropological) knowledge, as well as a space in which we build community, and where critical approaches to theorizing and social change can lead to emancipatory relations between students and teachers alike (hooks, 1989/2015; 1994/2014). Our claim is that counter-archiving in research and teaching can enable the re-telling of stories turned to whispers which are otherwise marginalized, shushed and erased in the university and history of knowledge/science generally, and that "[t]hese whispers confirm, in the words of Black transgender elder Miss Major, that we are "still fucking here" - that other ways of living together are possible" (Haritaworn, Moussa \& Ware, 2018, p. 9). 


\section{(Re)building: Course and Curriculum}

We are not alone in critiquing and demanding change within anthropology. Globally and locally, students have been at the forefront of organizing against whiteness, racism, cis- and heteronormativity at all levels of the AIC (Camufingo, 2021). At the department where we worked, some of these interventions include problematizations of the racism and cis-heteronormativity of the social introduction programs and the missing theorizing on oppressive structures on the curricula. Student's organizations have facilitated workshops and reading circles, written articles and staged interventions at department events. ${ }^{15}$ These resistances are mostly turned down by faculty and have rarely been taken up as central critiques of our discipline. Contrary, in our course, we engaged these critical reflections as part of our counter-archive, offering new building blocks to what we render a constructively unstable foundation of anthropology. Unstable foundations are constructive because they enable old walls to fall and weeds to grow and burst through the cracks and spread organically. Our course was an opportunity to water the seeds planted by student activists and to lift the critical approaches to knowledge from the margins into the center of the classroom. Rather than weeding out the critiques, we were interested in sustaining their growth and contributing to their spread beyond our course and into the wider anthropology program, the AIC and beyond.

The course was one of three electives within a compulsory program in applied anthropology and focused on normcritical approaches to discrimination related to gender, sexuality and race. The department's aim was for students to learn how to apply anthropological analysis in case-studies developed by a company, a government institution or an NGO. As teachers we chose the specific focus as well as the project partner. We established a collaboration with an NGO that works with discrimination on research and policy levels, who tasked the students with an analysis of discrimination within leisure activities for children and youth. Our course was organized in three stages: 1) seminarbased teachings and discussions on theory and methodology, 2) fieldwork with supervision, 3) writing a final report and preparing a presentation with findings and recommendations to the NGO.

We organized the course and curriculum (see figure 3) around our counter-archive. We engaged these materials to provide students with tools to critically evaluate, and sometimes unlearn, what they had been taught about what anthropology is and can be. The counter-archive is not restricted by the confines of what is considered 'academic' knowledge but is made up of both texts, music, videos, zines, podcasts and blogs. As part of our pedagogical and epistemological commitment to challenge who is reaffirmed as knowledgeable (Todd, 2016, p. 19; Smith, 1999), we explicitly and transparently discussed our selection of materials and citational politics with students. We

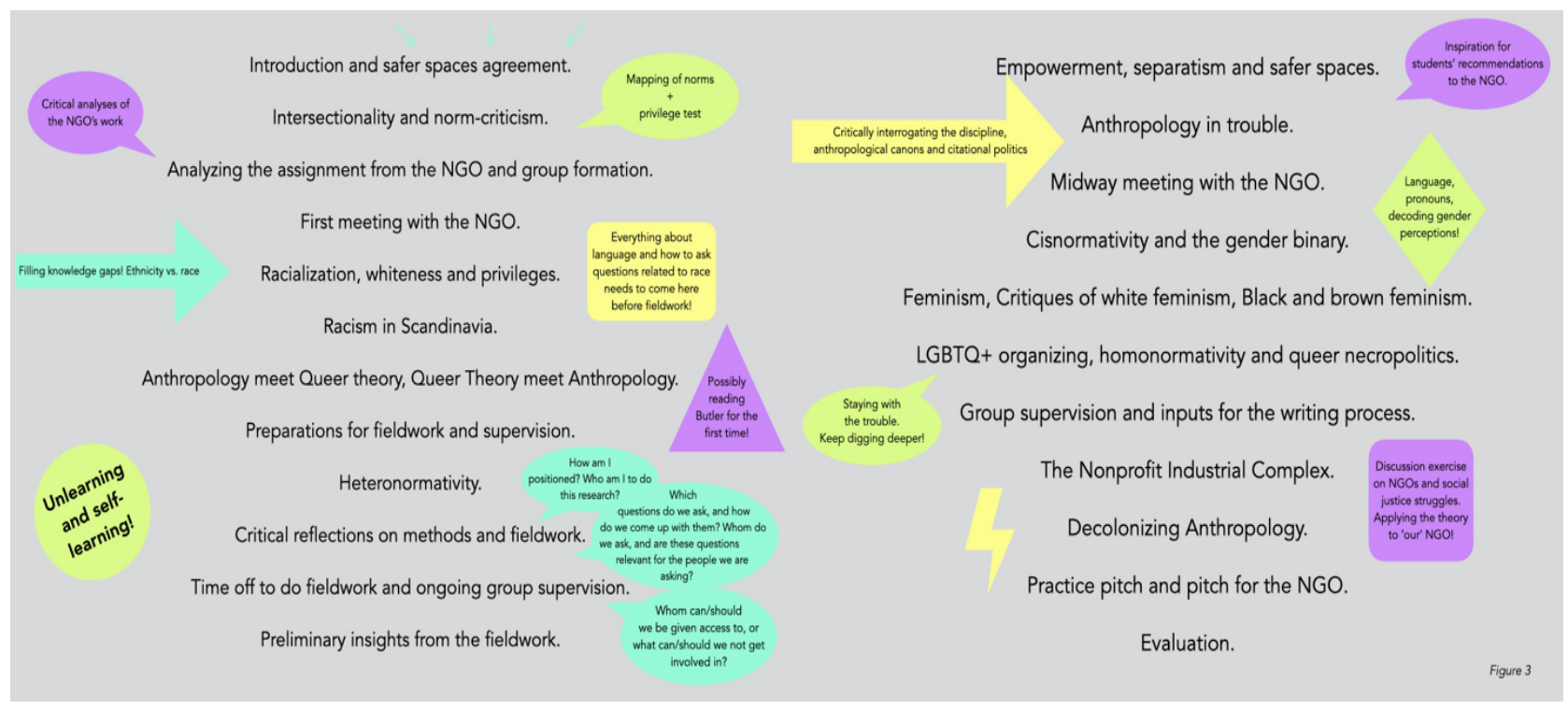

15 We would like to reference the specific organizations and their work but due to anonymization, we here mention various student organizations in Nordic countries that inspire and guide our work: African Student Association UiO, ASA Trondheim, Saemien Studeenth Tråantesne, SAIH, Steatornis, FKA, Front, SOCO, and the sexology students organizing against racism at Malmö Uni. 
predominantly chose materials in line with the demand of 'Nothing about us without us' 16 and through decentering the often-cited white, cis-hetero perspectives and centering QTIBIPOC ${ }^{17}$, BIPOC, queer and trans knowledge ${ }^{18}$. We also introduced the students to critiques of anthropology from within the discipline such as interventions by Black feminist anthropology and queer anthropology (Mullings, 2005; Bolles, 2013; Smith et al., 2021; Manalansan, 2016; Allen \& Jobson, 2016; Allen, 2016; Morgensen, 2012; Weiss, 2016).

While we continuously, and respectfully, borrow theories, methods and pedagogies from decolonial scholars, we believe that our course and collaborative project cannot be decolonial, because of its presumed distance from concrete decolonial struggles. Indigenous, anti- and decolonial thinkers continue to remind us that decolonization is not a metaphor (Tuck \& Yang, 2012) and that decolonization should not and cannot be safely 'contained' in the classroom (Araluen, 2017). Decolonial struggles are about demands for self-determination, land sovereignty and the continuance of Indigenous existence (Jensen, 2019; Laula, 1902). As non-Indigenous activist scholars, who are marginalized in the Neoliberal Imperial University, we meditate on how we can engage in anti- and decolonial projects, through citing and speaking with rather than appropriating Indigenous scholars? Métis scholar in biology, sociology and anthropology, Zoe Todd (2016, p. 18) reminds us that when anthropologists "sashay in and start cherry-picking parts of Indigenous thought that appeal to them without engaging directly in (or unambiguously acknowledging) the political situation, agency, legal orders and relationality of both Indigenous people and scholars, we immediately become complicit in colonial violence". Furthermore, Marronage (2019, p. 135) points out that white people (and settlers) discussing decolonial theory in a closed university setting cannot be considered decolonization. Such reflections must be transformed into concrete actions and accompliceship ${ }^{19}$ in political struggles.

Similarly, queer, trans and Black feminist epistemologies can never be separated from the struggles that birthed them nor from the calls to action they encompass. Scholar in Trans* studies in education, Nicolazzo (2019, p. 108) asks educators to consider their/our role in social transformation and suggests centering trans epistemologies through a trickle up education where we seek "to unearth, center, and spend time with those who are on the margins of the margins". Working alongside and spending time with 'those on the margins' and their/our knowledge entails a deep commitment to (un)learning about the structures, inside and outside the classroom, that shape their/our lives. In doing so we must push ourselves and our students to contextualize what we learn and take steps toward radical transformations of how we engage in the classroom, anthropology, political movements, personal relationships, and how we live on/with Earth. Our counter-archival, trickle up pedagogy thus requires that we transgress the classroom and let these teachings have ripple effects in our lives.

Examples of how we did this include discussing the power of categorizations in media discourses as well as in texts produced in the AIC and collectively questioning how or if to categorize people in the students' projects. Listening to the demands from queer and trans theorizing, our students began to question binary gender terminologies and learned that asking for, respecting and not assuming people's pronouns and gender, is just as important as understanding queer, feminist philosopher Judith Butler's (1990) performativity theory. We also read texts that would help the students dare to notice and speak openly of race $^{20}$ beyond the theoretical realm of class discussion, and to understand how gender, sexuality, class and body shape are deeply racialized constructs that figure in every and all aspects of their lives (Combahee River Collective, 1983/1978).

When putting together the syllabus and seminars we carefully considered which reflections and knowledge to introduce first and when students would be 'ready' to take further steps. Many students were for example new to queer and trans theories and had difficulties smashing the binaries we have all been taught to uphold, including

\footnotetext{
16 The queer disabled femme writer, organizer, performance artist and educator of Burgher/Tamil Sri Lankan and Irish/Roma ascent Leah Lakshmi Piepzna-Samarasinha (2019, p. 24) traces the origin of this phrase to disability justice groups in South Africa in the 1980s and 90s.

${ }^{17}$ Queer, Trans, Intersex, Black, Indigenous, People of Color.

${ }^{18}$ For literature on critical Black feminist citational practices in anthropology, check out Bolles, 2013; Smith et. al., 2021.

${ }_{19}$ We use the term accompliceship rather than ally or allyship as a critique of the Ally Industrial Complex and the commodification and exploitation of allyship (Indigenous Action Media, 2014).

${ }^{20}$ Instead of promoting 'color-blindness' or a 'bracketing of race' (Wekker, 2016).
} 
essentialist, biological determinist understandings of gender which erase trans and intersex existence. Furthermore, we continuously evaluated which discussions to have before the fieldwork. For instance, many students expressed discomfort and insecurity in talking to project participants about racialization. Other students' misgendering of project participants and fellow students made us aware that we needed to continuously tackle this head on in class.

\section{Safer and brave space agreement}

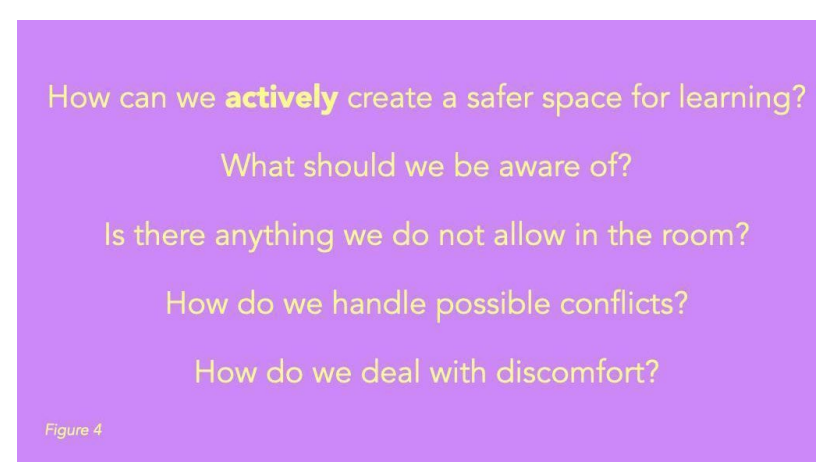

At the beginning of the course, we discussed how to create a safer and brave space for collective learning. Safer and brave space agreements are a common practice in many queerfeminist, Black feminist and QTIBIPOC ${ }^{18}$ spaces and function as guidelines and ongoing dialogue for how to coexist, organize, care for each other and/or learn together. Safer and brave space agreements reflect an understanding that, as decolonial feminist and international studies scholar Rosalba Icaza and lecturer in politics Sara de Jong (2019, p. $\mathrm{xv})$ note in their approach to critical decolonial feminist pedagogies, students are co-responsible for the creation of the collective learning space and that teachers are learners as well. Safer and brave space discussions and agreements aim at making the space safer recognizing that they can never be safe for everyone at the same time, at all timesat all times. Such an agreement includes recognizing that we continually do harm to each other under white supremacist, colonial, capitalist, ableist, cis-hetero patriarchy and that "We are not over it; it is not over" (Ahmed, 2014, para. 31) nor will it be in the near future.

Therefore, we need to create language and structures that enable us to hold each other accountable and learn from our mistakes so we can do better in the future. In learning spaces, especially when analyzing oppressive structures, how we can dismantle them, and how we are simultaneously hurt by and complicit in them, participants must be brave. Brave because we are bound to be hurt, cause harm, make mistakes and feel discomfort. Yet, we must continue to be and participate actively in these spaces. Such agreements can include reflections on how to step up/down, how to give or hold space, how and when to call in/out, how to take responsibility and hold yourself and others accountable. Practically, we went about this discussion by dividing students

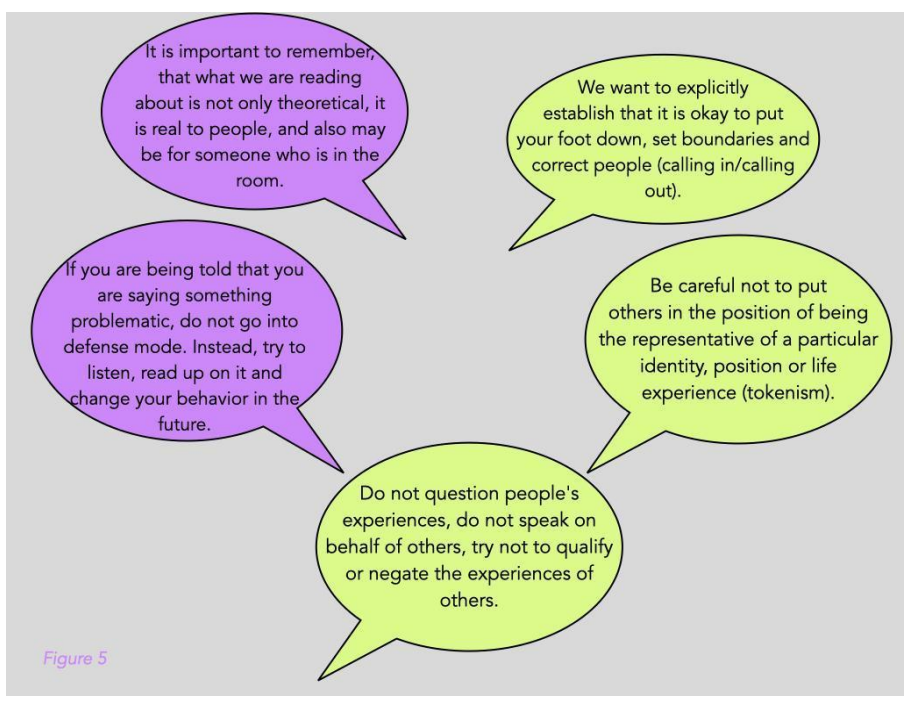
into random groups of 3-5 people where they discussed the questions in figure 4. We let the students talk without us, and then proceeded to hear inputs from all the groups. Some inputs caused discussions, for instance when someone said 'there are no stupid questions' wanting to create a space where we would not be afraid to ask questions, and someone else added that this does not mean it is okay to question someone's experiences or identity. 
What are the benefits of being granted these privileges?

How are you (also unintentionally) part of reproducing different norms? And what can you do to change it?

How do your positions and privileges affect your worldview, research practices, analysis and work? For example, what can you see / not see from your position? Which questions do you ask / do you not ask in the field? How do you interpret what people say? Figure 6
During the discussion, our reflections and interventions were written on the whiteboard and then in a collective agreement, which also included resources for further reading ${ }^{21}$, and was shared on our intranet.

On figure 5 from the zine is a small selection of the agreement we made. The agreement had a double function as it sparked instant discussion and was used as reference in future situations. The classroom discussion and agreement were accompanied by a Privilege test/reflection exercise where we briefly went through a - not finite - list of privileges and asked the students to reflect on how their privileges affect their research practices (see figure 6).

\section{Reorientation: the classroom}

Throughout the course we actively worked to reorient the classroom by enabling discussions, making room for doubts and for possibilities to learn and change position. We aimed to question and break down classroom hierarchies and our authority as teachers by openly stating doubts, insecurities and not delivering finite answers. Black lesbian feminist educator bell hooks' reading of Paulo Freire, inspires us to disrupt an educational order where knowledge is passed from the knowing, powerful teacher to the unknowing powerless student, as we aim to educate for liberation and not for domination (hooks, 1994/2014). Reorienting the classroom from top-down to collaborative learning included physically rearranging the classroom, so that students were sitting in groups facing each other rather than in rows facing the teacher (see figure 7 ).

Furthermore, we incorporated a variety of exercises such as individual writing prompts, drawings, brainstorms and mind maps, in groups and collectively on the whiteboard, and by enabling

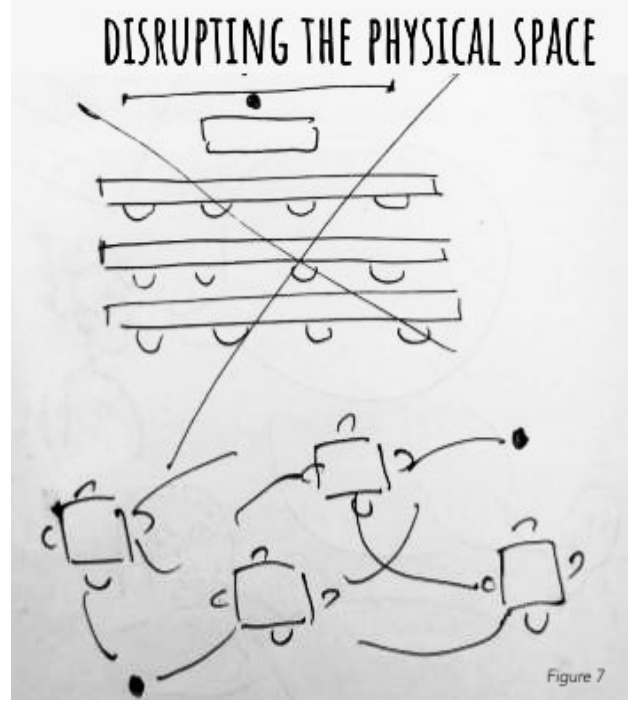
students to ask questions or share reflections anonymously on sticky notes, either on paper or online.

We also used scale exercises (see figure 8) as a tool to discuss a standpoint and allow for both nonverbal and verbal reflections and discussion. In the scale exercises we would phrase a standpoint, for instance: 1) "Anthropology gives us the opportunity to investigate oppressive structures and mechanisms of exclusion", 2) "Anthropology can help

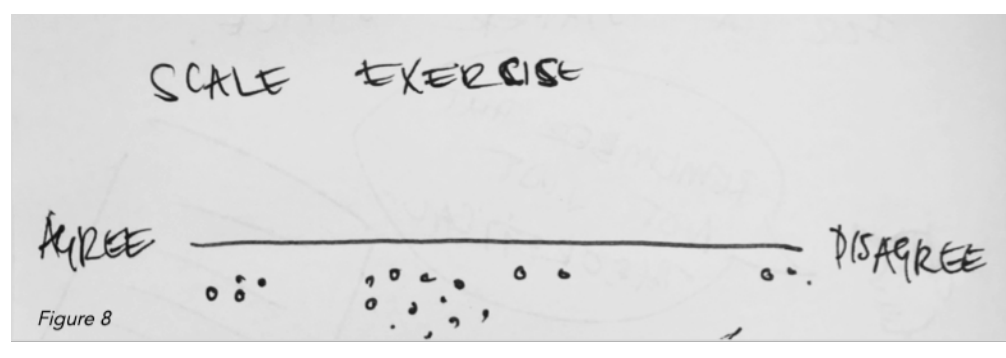

us change oppressive structures and mechanisms of exclusion", 3) "Change cannot be brought from the university/an NGO/a consultancy firm (it has to happen from the grassroots, outside the establishment)", and the students then had to place themselves on a scale according to whether or not they agreed. We would ask them to share reflections on where they were placed on the scale and allow

for students to move around on the scale as they listened to each other's reflections. This exercise made the students more aware of their presuppositions as well as what they wanted to work towards achieving in their groups.

\section{Reversing the Gaze}

As most university classrooms in Scandinavia, this classroom was predominantly white, cis, and middle/upper class. The fourth semester students in our course had been taught a similar canon as the one we had been through years

${ }^{21}$ Here are some resources we shared: Trần (2014), McKenzie (2015). 
before, and the ideal of the 'good' anthropologist who strives for objectivity and gives voice to marginalized people, was very prevalent among them. It was therefore not only theoretically challenging but also emotionally frustrating for many of the students to read e.g., Bolles (2013) on how Black thinkers have been excluded from anthropology, Mohanty (1984) on the dangers of Western feminism, and Shanklin (1999) on anthropological colorblindness, that all made them realize the coloniality and violent history of anthropology.

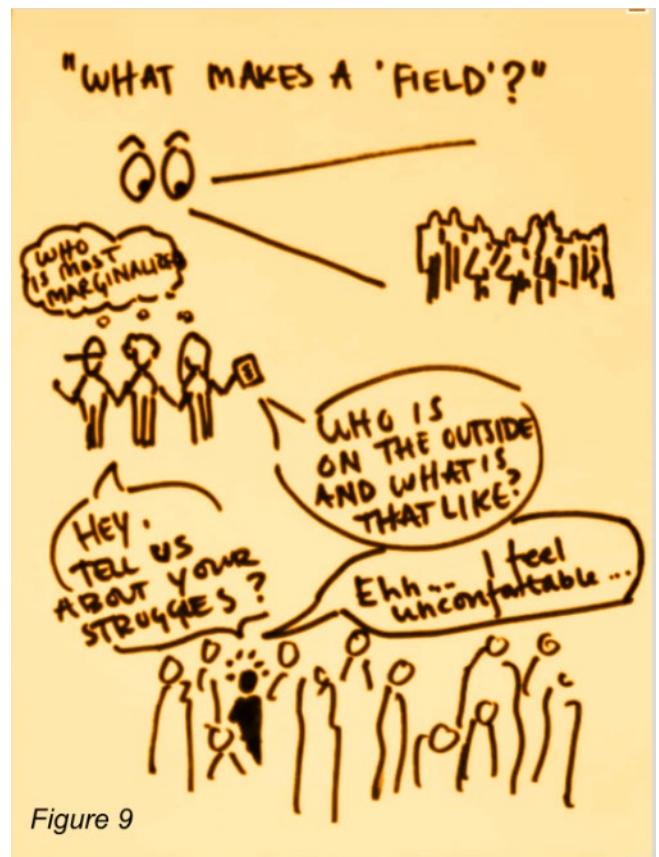

As they began to choose their field of interest for the NGO assignment, most groups were initially drawn to questions and research designs that singled out those who were presumed most marginalized in a given sports or leisure group. In their interest to understand racism, they would plan to point out and count the few BIPOC in a group and ask them how it feels to be an outsider. When investigating misogyny, some would look for women whom they deemed most discriminated against, in this case women who wore headscarves. This inclination seemed to come from the idea of gathering 'proof' of the discrimination that was taking place, and that the best way to do this was through personal testimony and pain narratives (see figure 9). We recognize this tendency, not only within Western social science (Tuck \& Yang, 2014), but also in mainstream media, and could understand how the students thought this would be the most reasonable approach. We therefore aimed to help them be aware of and critically reflect on their situatedness and positionality and on the hidden structures that were at play in the discipline, in the field sites as well as in their own lives. The classroom became a place in which they learned to reverse, and in a sense then also to subvert, their anthropological gaze from margin to center by examining the very logics and norms that governed the spaces they were interested in instead of shedding the spotlight on the few social outliers (see figure 10).

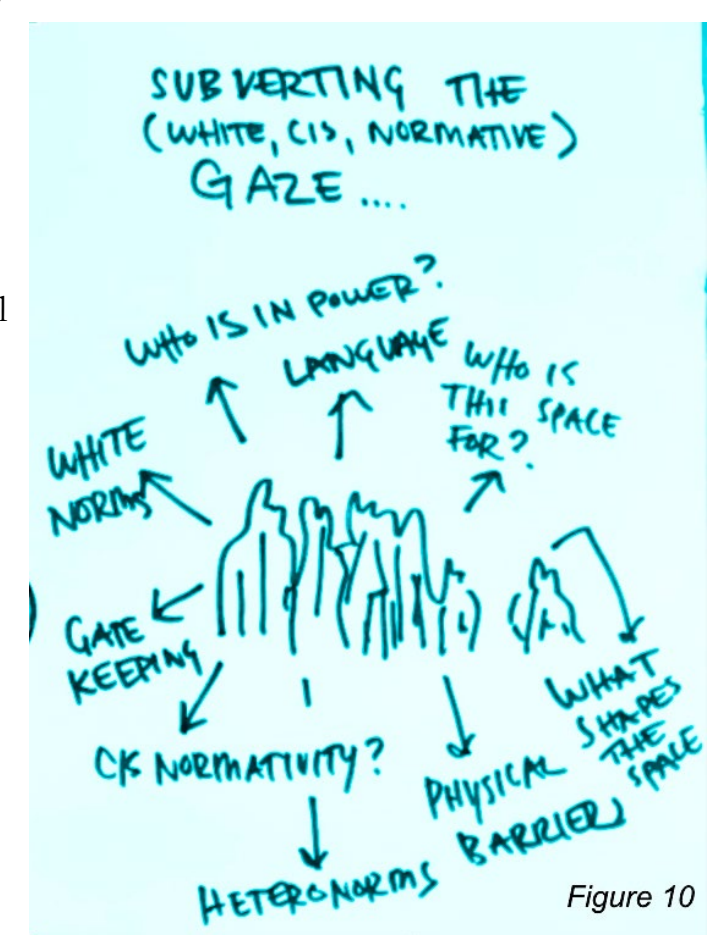

The counter-archive assisted us in exploring the colonial history of anthropology and patterns of extractivism and data mining in anthropological research (Smith, 1999; Harrison, 1991/1997). By challenging and disrupting this tendency through collective theorizing, we explored what positionality means for the work we are able to do, the questions we are able to ask in our research (see figure $\sigma$ ) and who our research benefits. In our reading of feminist texts, we decentered white feminism by rejecting the idea of the four feminist waves. By engaging queer, trans and anti-colonial critiques of the NGO Industrial Complex we enabled the students to critically analyze and answer to the assignment from the NGO and to question the logics behind creating change through policy. Through reflexivity on both personal, social, disciplinary and methodological levels, the students designed projects that were norm-critical instead of normative. Some groups looked into the organization of football clubs, and the structure of communication between trainers, players and parents, incorporating issues of gentrification and funding through diversity policies. Some groups explored sports exclusively for women, non-binary (and) trans people as spaces of empowerment, while others discovered the links between white nationalism, Christian values and forced gender binaries in scout organizations. 


\section{Deliberate discomfort}

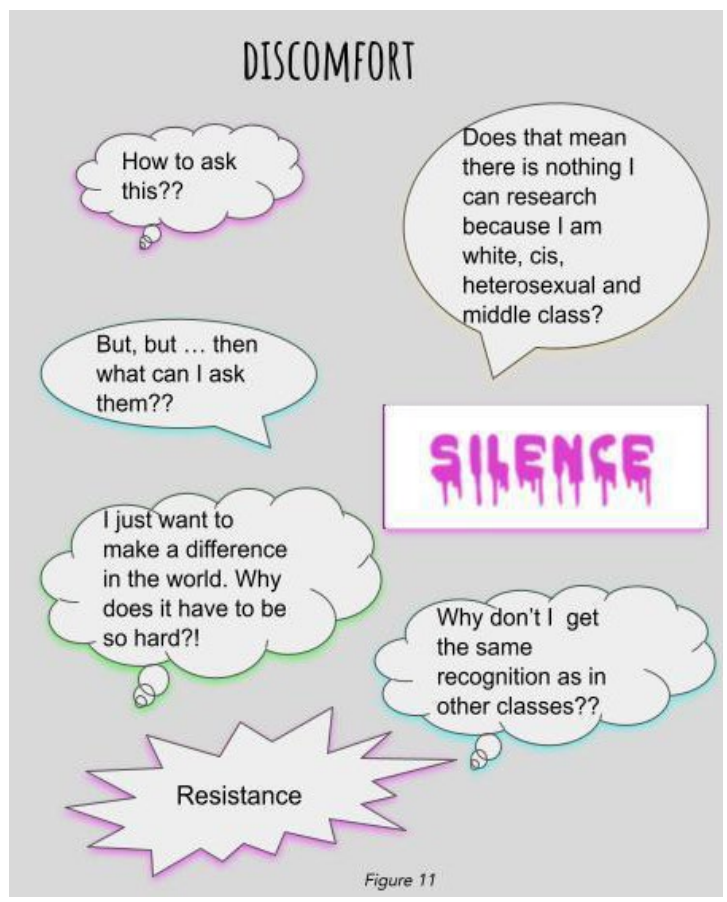

Invoking and dealing with discomfort is a central part of our pedagogy, and a way of deliberately glitching the university machine (Hammana \& Klinkert, 2021). Because of their positionalities, most of our students had presumably been moving through the world and the AIC without being stopped by brick walls of oppression (Ahmed, 2017) and were used to being praised and not questioned in their academic endeavors, which manifested as entitlement in the classroom. At the beginning of the course, we thus prepared the students for the presence of discomfort in the safer and brave space exercise. Even so, their encounter with norm-critical and anti-oppressive approaches not only challenged them scholastically but also personally. Realizing how they in various ways are complicit in upholding harmful structures incited pain and discomfort which surfaced as deafening silences, shouting and tears. Some students found it difficult to utter the words "race", "whiteness", "cisnormativity" and "heteronormativity". They would avoid these words by using seemingly 'neutral', colorblind language such as "different gender", "different skin color", or "different ethnic background"22 (see figure 11).

As noted by feminist writer and independent scholar Sara Ahmed (2014, para. 16) we have to work and struggle "to notice what causes hurt, which means unlearning what we have learnt not to notice. We have to do this work if we are to produce critical understandings of how violence, as a relation of force and harm, is directed toward some bodies and not others." Ahmed continues, that "to unsee the world as you learnt to see it, the world that covers unhappiness, by covering over its cause. You have to be willing to venture into secret places of pain" (Ahmed, 2014, para. 16). Not initially prepared to venture into these 'secret places of pain', the students would avoid sitting with discomfort and instead move towards innocence (Wekker, 2016) by attempting to quickly resolve oppression to then "resume business as usual" (Allen \& Jobson, 2016, p. 138; Harrison, 1991/1997). The discomfort of interrogating the racial and colonial logics of anthropology sparked questions such as "If I'm white, then what can I even do?" (see figure 11), which we interpret as another attempt to avoid acknowledging the harm by re-centering oneself (Camufingo, 2021). Some would also reject the counter-archive by referring to the 'Reflexivity debate', which was introduced in their first-year curriculum, as something that was over and done with.

We facilitated discomfort by being transparent about our own difficulties, doubts, mistakes and learning processes. Here, we also actively worked with being two teachers in the room. Sometimes this opened up the possibility of Nico sharing reflections on whiteness or for the both of us to share experiences with resistances related to racism, gender and anti-trans structures in the university as well as with how we have or have not been questioned and called in/ out. By sharing our own learning trajectories, we tried to open the space for the students to be honest and less afraid of learning, changing and thus inevitably also making mistakes.

Slowly, but surely the students gained more confidence and found more meaning in the discussions and course materials. They became aware of hidden harmful structures everywhere, as if it were a set of glasses that could not be taken off again. They began to use their discomfort and emotional knowledge as a critical lens which helped them ask the necessary questions to strengthen their projects. Through utilizing their discomfort as a driving force, they were able to "check" themselves and each other, through asking questions such as "why are we interested in this

22 Essed, 1991 and Habel, 2011, point out this (European) tendency to use 'ethnicity' as a means to avoid mentioning race while upholding racialization. 
field?", "what are our different positionalities and relations with the field, and what does it mean for our ability to relate to our participants?", "how can we be useful and not harmful?", "which spaces and people are we able to access, that others are not?". They found motivation in understanding the potential they had to create knowledge in new ways and to provide insight in a largely uncovered field through their developing critical sense.

\section{Responding to resistances: Towards a pedagogy of accountability and care}

As the above section illustrates, our decentering of whiteness and cis-heteronormativity and use of discomfort sparked a lot of resistance both within and around the classroom. In the following we reflect on how we engage resistance through a pedagogy of accountability and care.

Moving through the world and the AIC as 'bodies out of place' means that we expect and are familiar with resistance. We interpret resistance as a sign that we are unsettling dominant 'truths' and thus understand resistance as constructive. When the students resist knowledge that requires them to rewire their brains and take in new ways of analyzing oppressive structures, we strive to meet them with humility, flexibility and care. This means that we continuously analyze the power dynamics within the classroom, both between differently positioned students and in student-teacher relations. Discomfort and resistance coming from those who were most often centered in other classrooms, could risk shrinking the space further for the students that were marginalized in classrooms and generally. To share space, we had to take and give space differently. Sometimes, we had to stop harmful behavior in the classroom or point out the problematic and harmful statements that were made, in this way disrupting racial and cisnormative logics and how this marks not only "whose knowledge is dominant and considered legitimate" but also "whose emotions have a right to be" (Camufingo, 2021). We would direct expressions of white tears"23 and anti-trans violence away from the shared space and the people who experience these structures on a daily basis. Calling students in and facilitating a caring learning space with one of us as teachers, we took responsibility for the students expressing frustration and interest in learning without placing that responsibility and emotional labor on everyone in the classroom. That being said, it was often a difficult line to walk, and we constantly negotiated and reflected on when to call out or in and when to not engage further.

We believe that our collective agreement to be vulnerable and brave made it possible for teachers and students alike to hold each other accountable and say out loud when something did not sit right with us, when something hurt or when we were feeling insecure. Black feminist and critical education scholar Esther Ohito (2018) writes about a critical pedagogy of love that requires a willingness to learn through both thought and the body. She writes that a critical pedagogy of love can disrupt classroom oppression by fostering joy, pleasure and community. In our classroom, the combination of facilitating discomfort and holding space for vulnerability and emotional learning enabled structural transformation. These pedagogies of resistance, accountability and collectivity are not finished approaches, but ideas in constant development as we learn and grow as teachers, activists and researchers. Our choice of political transparency was not without costs, both to our mental health and with the risk of making mistakes. We could not know how our pedagogies would turn out in practice nor which kind of institutional resistance we would meet. It was therefore vital for us to support each other throughout the process.

A particular instance of institutional resistance happened at the final meeting with the NGO. As a result of our collective learning and development of norm-critical, anti-oppressive fieldwork and discussions, the students' projects had moved away from asking questions such as "what does it feel like to be excluded?" towards interrogating the structures at play in their respective fields. This approach informed the recommendations that they presented to the NGO, in which the students suggested that the NGO moved towards an intersectional approach to

23 We could not find an original source for "white tears". However, Audre Lorde, 1984, among other Black feminists describe the political use of emotions and tears, particularly among white cis women, as a move to innocence and control. 
research and report writing. Another central recommendation was that the research team should somehow reflect the positionalities of the people they work with. The students pointed out that participating in research on marginalization can feel unsafe and re-traumatizing for some, which is why hiring researchers that are familiar with the particular discriminations themselves, as well as shifting the focus from the oppressed to the oppressive structures, would provide better circumstances for the people involved. These recommendations sparked a strong reaction and resistance from the case-giver, who shouted, "you don't have to be one to study one!!" and asked if they wanted to "erase the whole history of anthropology?!" (see figure 12). This experience was extremely awkward and uncomfortable, and left the students shocked, particularly those who had been the target of the resistance. The way we as teachers reacted reflects our pedagogy of accountability and care. Nico approached the casegiver, talked them down from their rage and held them accountable for their reaction while Oda-Kange took care of the shocked students outside. We then managed to finish the presentations and organized a collaborative analysis and care

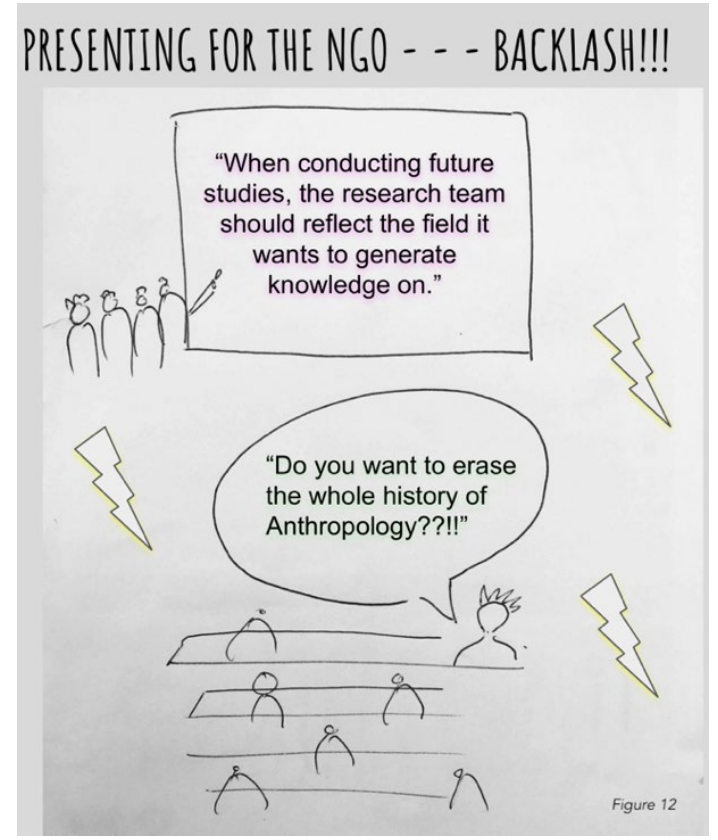
session back at campus. While sitting in the campus garden and eating ice-cream, we discarded the planned afternoon class and talked about how and why, what we deemed comprehensive and wonderful presentations and recommendations, were met with resistance and white, cis discomfort and fragility (see figure 13). We thus gave space for the students' feelings and assisted each other in realizing that these are the structures and mechanisms we have been discussing all semester.

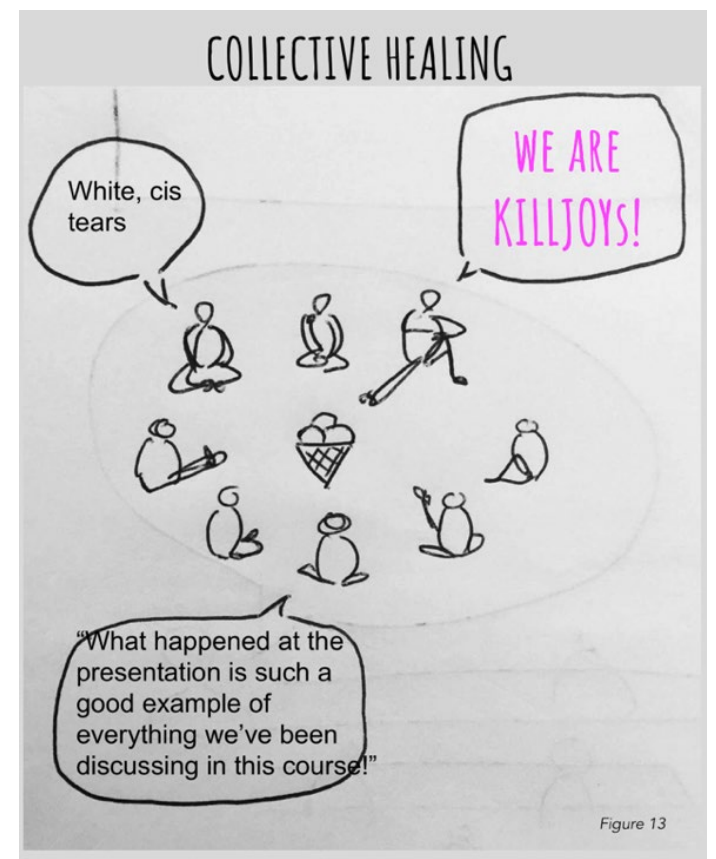

The story leaves us back at its beginning, namely at the question of whether we want to erase the whole history of anthropology. This question reveals the inability to understand what and who is actually being erased. So, our answer is $\mathrm{NO}$, we are not erasing history! Rather, we want to dig out the BIPOC, queer, trans, QTIBIPOC (and other) treasures which have been buried, erased and appropriated by the racial and colonial logics of the anthropology canon and the AIC at large. Scholar in anthropology, Black diaspora, feminist and queer studies Jafari Sinclaire Allen and anthropology and Black studies scholar Ryan Cecil Jobson (2016, p. 133) suggest that "decolonizing anthropology should not be understood as a closing off of anthropology or the shrinking of its intellectual purchase but rather as an opening of its inquiry beyond the constrained limits into which it had been disciplined ". The counter-archive that we continue to expand offers us a means to open up such spaces, dig up treasures and expose the ugly truths of the history of anthropology and the structures that it continues to uphold by not being named: precisely, what is rendered knowledge, and who can be knowledgeable? What has been and is still done to people in the name of science? (How) can teaching-research-

activism in, around and outside anthropology contribute to uplifting the struggles under white supremacist, colonial, capitalist, ableist, cis-hetero patriarchy? How can we organize collectively against the structures that try to keep us out, through accountability and care? 
Teaching Anthropology 2021, Vol. 10, No. 4, pp. 17-35

\section{References}

Abrahams, N. (2021). On being a space invader and the thing around my neck. Teaching Anthropology, 10(4), 73-83.

Abu-Lughod, L. (1990). Can There Be A Feminist Ethnography? Women \& Performance: a journal of feminist theory, 5(1), 7-27. https://doi.org/10.1080/07407709008571138

Ahmed, S. (2014, July 21). Feminist Hurt/Feminism Hurts. feminist killjoys. https://feministkillioys.com/2014/07/21/feminist-hurtfeminism-hurts/

---- (2017), Living a Feminist Life. Duke University Press. https://doi.org/10.1215/9780822373377

Aizura, A. Z., Cotten, T., Balzer, C./Lagata, C., Ochoa, M. and Vidal-Ortiz, S. (2014). Introduction:

Decolonizing the Transgender Imaginary. TSQ: Transgender Studies Quarterly, 1(3), 308-319.

Allen, J. (2016). One View from a Deterritorialized Realm: How Black/Queer Renarrativizes Anthropological Analysis. I: Cultural Anthropology, 31(4),617-626. https://doi.org/10.14506/ca31.4.10.

Allen, J. and Jobson, R. C. (2016). The Decolonizing Generation: (Race and) Theory in anthropology since the Eighties. Current Anthropology, 57(2), 129-148. DOI:10.1086/685502

Alm, E., Berg, L, Hero, M. L., Johansson, A., Laskar, P., Martinsson, L., Mulinari, D. and Wasshede, C. (eds.) (2021). Pluralistic Struggles in Gender, Sexuality and Coloniality. Challenging Swedish Exceptionalism. Palgrave. https://doi.org/10.1007/978-3-030-47432-4

Araluen, E. (2017). Resisting the institution. Overland (227), 3-10. https://search.informit.org/doi/10.3316/in formit.044581458256335 (Original work published June 2017)

Arce, J. \& Suárez-Krabbe, J. (2018). Racism, Global Apartheid and Disobedient Mobilities: The Politics of Detention and Deportation in Europe and Denmark. KULT. Postkolonial Temaserie, 15, 107-127. http://postkolonial.dk/wp-content/uploads/2017/09/11 Julia-og-Jose We-are-here-because-youwere-there final.pdf

Bacchetta, P., El-Tayeb, F., Haritaworn J., Hernandez, J., Smythe, S., Thompson, V. E. and Willoughby-Herard, T. (2018). Queer of Color Space-Making in and beyond the Academic Industrial Complex. Critical Ethnic Studies, 4(1), 44-63. https://doi.org/10.5749/jcritethnstud.4.1.0044

Bassichis, M., Lee, A., and Spade, D. (2011). Building an abolitionist trans and queer movement with everything we've got. In Smith, N. \& Stanley, E. A. (eds.), Captive Genders: Trans Embodiment and the Prison Industrial Complex: AK Press, pp. 15-24.

Bolles, L. (2013). Telling the story straight: Black feminist intellectual thought in anthropology. Transforming anthropology, 21(1), 57-71. https://doi.org/10.1111/traa.12000

Boatwright, T. (2019). Flux Zine: Black Queer Storytelling. Equity \& Excellence in Education, 52(4), 383-395. https://doi.org/10.1080/10665684.2019.1696254

Bouteldja, H. (2016). Whites, Jews and Us: Toward a Politics of Revolutionary Love. semiotext(e)

Butler, J. (1990). Gender Trouble. Feminism and the Subversion of Identity. Routledge. https://doi.org/10.4324/9780203824979 
Camufingo, A. (2021). When We feel: Racialized Emotions and Epistemic Violence in German Higher Education. Teaching Anthropology, 10(4), 58-67.

Chen, M. Y. (2012). Animacies: Biopolitics, Racial Mattering, and Queer Affect. Duke University Press. https://doi.org/10.1215/9780822395447

Collins, P. H. (2000). Black Feminist Thought: Knowledge, consciousness and the politics of empowerment. Routledge. https://doi.org/10.4324/9780203900055

Combahee River Collective (1983). The Combahee River collective statement. In B. Smith (ed.), Home girls, a black feminist anthology. Kitchen Table: Women of Color Press. Rutgers University Press, pp. 264-274. (Original work published 1978)

Cohen, C. J. (1997). Punks, Bulldaggers, and Welfare Queens: The Radical Potential of Queer Politics? GLQ, 3(4), 437-465. doi: https:// doi.org/10.1215/10642684-3-4-437

de Jong, S., Icaza, R., \& Rutazibwa, O.U. (eds.) (2019). Decolonization and Feminisms in Global Teacbing and Learning. Routledge. https://doi.org/10.4324/9781351128988

El-Tayeb, F. (2011). European Others: Queering Ethnicity in Postnational Europe. University of Minnesota Press.

Essed, P. (1991). Understanding Everyday Racism: An interdisciplinary theory (2nd ed.). Sage. http://dx.doi.org/10.4135/9781483345239

Gilmore, R. W. (2007). Golden gulag: Prisons, surplus, crisis, and opposition in globalizing California. University of California Press.

Habel, Y. (2011). Challenging Swedish exceptionalism? Teaching while Black. In K. Freeman \& E. Johnson (eds.), Education in the Black diaspora: Perspectives, challenges, prospects: Routledge, pp. 99-122. https://doi.org/10.4324/9780203152973

Hammana, Z., \& Klinkert, V. L. (2021). Glitching the University Machine. Teaching Anthropology, 10(4), 36-46.

Haritaworn, J., Kuntsman, A., and Posocco, S. (eds.) (2014). Queer necropolitics. Routledge. https://doi.org/10. 4324/9780203798300

Haritaworn, J., Moussa, G., and Ware, S. M. (eds.) (2018). Marvellous Grounds: Queer of Colour Histories of Toronto. Between the Lines.

Harney, S., \& Moten, F. (2013). The Undercommons: Fugitive Planning \& Black study. Minor Compositions. https://www.minorcompositions.info/wp-content/uploads/2013/04/undercommons-web.pdf

Harrison, F. V. (ed.) (1997). Decolonizing anthropology: Moving Further Toward an anthropology for Liberation. American Anthropological Association (Original work published 1991)

hooks, b. (2014). Teaching to Transgress. Education as the Practice of Freedom. Routledge. https://doi.org/10.43 24/9780203700280(Original work published 1994)

---- (2015). Talking Back: Thinking Feminist, Thinking Black. Routledge (Original work published 1989)

Indigenous Action Media (2014). Accomplices Not Allies: Abolishing the Ally Industrial Complex. An Indigenous perspective, [Zine]. https://bit.ly/38iumrm 
Jensen, E. M. (2019). Conceptualizing Oktavuohta as a Storytelling Methodology in Sámi Research. Dutkansearvvi dieđalaš áigečála, 4(1), 4-27.

Jobson, R. C. (2021, January 28). Is it possible to decolonize anthropology? Theory from the margins with Kamari M Clarke and Ryan C Jobson [Video]. YouTube. https:/ / www.youtube.com/watch?v=FYhTCrETx4o

Johnson, E. P. (ed.) (2016). No Tea, No Shade: New Writings in Black Queer Studies. Duke University Press.

Jourian, T.J. and Nicolazzo, Z. (2017). Bringing our communities to the research table: the liberatory potential of collaborative methodological practices alongside LGBTQ participants. Educational Action Research, 25(4), 594-609. DOI: 10.1080/09650792.2016.1203343.

Khalid, F. (Host). (2020). Mere end mursten. En podcast om ghettopakken [Audio podcast]. Respons. https://www.responsmedie.dk/podcast-ghettopakken/

Kilomba, G. (2010). Plantation Memories: Episodes of Everyday Racism. UNRAST-Verlag.

Laula, E. (1902). Inför lif eller död: Sanningsord i de lappska förhållandena. Wilhelmssons Boktryckeri.

Levya Solano, X. (2019). Undoing colonial patriarchies: life and struggle pathways. In de Jong, S., Icaza, R., \& Rutazibwa, O.U. (eds.), Decolonization and Feminisms in Global Teaching and Learning. Routledge, (pp. 4359). https://doi.org/10.4324/9781351128988

Linander, I., Alm, E., Goicolea, I., and Harryson, L. (2019). "It was like I had to fit into a category": Care- seekers' experiences of gender regulation in the Swedish trans-specific healthcare. Health, 23(1), 21-38.

Lorde, A. (1984). Sister Outsider. Random House.

Lugones, M. (2010). Toward a Decolonial Feminism. Hypatia 25(4), 742-759. doi:10.1111/j.1527-2001.2010.01137.x

Manalansan IV, M. F. (2018). Messing up sex: The promises and possibilities of queer of color critique. Sexualities, 21(8), 1287-1290. https:// doi.org/10.1177/1363460718794646

Manalansan IV, M. F. (2016). Queer Anthropology: An Introduction. Cultural Anthropology, 31(4), 595-597. https://doi.org/10.14506/ca31.4.07

Marronage (2017a). Marronage no. 1. In Sherfig, A., Nehemiah Antonio Harrison, Y., Na Blankholm, L., Kim Kramhøft, L., Kiwi, N., Weis Damkjær., N., Wathne, S., \& Skadegaard, T. S. (Eds.), Forlaget Nemo.

Marronage (2017b). Marronage no. 2. In Sherfig, A., Elg, E., Na Blankholm, L., Kim Kramhøft, L., Løvholm, L., Takawira, M., Kiwi, N., Weis Damkjær, N., Cramer, N., Wathne, S., Skadegaard, T. S., \& Nehemiah Antonio Harrison, Y. (Eds.), Forlaget Nemo.

Marronage (2017c). Marronage no. 3. In Sherfig, A., Meera Gainkar, A., Elg, E., Na Blankholm, L., Kim Kramhøft, L., Løvholm, L., Takawira, M., Lang, M., Weis Damkjær, N., Cramer, N., Ahrong G. Nissen, P., Wathne, S. \& Nehemiah Antonio Harrison, Y. (Eds.), Forlaget Nemo.

Marronage (2019). The white gaze within the structure. In Critical Friends (Eds.), Actualise Utopia. From dreams to reality. "An anthology about racial barriers in the structure of the Nordic Arts Field.", (pp. 99-136).

McIntosh, L. (2014). Before and after: Terror, extremism and the not-so-new Norway. African and Black Diaspora: An International Journal, 7(1), 70-80. https://doi.org/10.1080/17528631.2013.858921 
McKenzie, M. (2015, November 4). How to Tell the Difference Between Real Solidarity and 'Ally Theater'? Black Girl Dangerous. http://www.blackgirldangerous.com/2015/11/ally-theater/

Mendes, J-T. (2020). Black Death, Mourning and The Terror of Black Reproduction: Aborting the Black Muslim Self, Becoming the Assimilated Subject. Souls (Boulder, Colo.), 22(1), 56-70. https://doi.org/10.1080/10999949.2020.1804803

Mohanty, C. (1984). Under Western Eyes: Feminist Scholarship and Colonial Discourses. Boundary 2(12/13), 333-358. https://doi.org/10.2307/302821

Morgensen, S. L. (2012). Destabilizing the Settler Academy: The Decolonial Effects of Indigenous Methodologies. American Quarterly 64(4), 805-808. 10.1353/aq.2012.0050

Mullings, L. (2005). Interrogating Racism: Toward an Antiracist Anthropology. Annual Review of Anthropology 34, 667-93. https://doi.org/10.1146/annurev.anthro.32.061002.093435

Muñoz, J. E. (1999). Disidentifications/ Queers of Color and the Performance of Politics. University of Minnesota Press.

Nebeling Petersen, M. (2016). “These are queer times indeed": En introduktion til homonationalisme i en dansk kontekst. Kvinder, Kon \& Forskning, 16(4), 55-66. https://doi.org/10.7146/kkf.v25i4.104399

Nicolazzo, Z. (2019). In Search of Her: An Autoethnographic Search For Self in Virtual Landscapes. Thresholds in Education, 42(1), 106-123.

https://academyedstudies.files.wordpress.com/2019/11/th42 1nicolazzofinal.pdf

Ohito, E. O. (2019). “I Just Love Black People!” Love, Pleasure and Critical Pedagogy in Urban Teacher Education', The Urban Review (51), 123-145. https:/ / doi.org/10.1007/s11256-018-0492-7

Pearce, R. (2020). A Methodology for the Marginalised: Surviving Oppression and Traumatic Fieldwork in the Neoliberal Academy. Sociology 54(4), 806-824. https://doi.org/10.1177/0038038520904918

Piepzna-Samarasinha L. L. (2019). Care work. Dreaming disability justice (Fourth Printing). Arsenal Pulp Press. (Original work published 2018)

Puar, J. (2007). Terrorist Assemblages: Homonationalism in Queer Times. Duke University Press. https://doi.org/10.1215/9780822390442

Puwar, N. (2004). Space Invaders: Race, Gender and Bodies Out of Place. Berg Publishers.

Raha, N. (2017). Transfeminine Brokenness, Radical Transfeminism. South Atlantic Quarterly, 116(3), 632-646. https://doi.org/10.1215/00382876-3961754

Rodríquez, D. (2017). The political logic of the non-profit industrial complex. In Incite! Women of Color Against Violence, (Eds.), The Revolution Will Not Be Funded: Beyond the Non-Profit Industrial Complex, (pp. 21-40), Duke University Press. https://doi.org/10.1215/9780822373001(Original work published 2007)

Sager, M and Mulinari, D. (2018). Safety for whom? Exploring femonationalism and care-racism in Sweden. Women's Studies International Forum, (68), 149-156. https://doi.org/10.1016/i.wsif.2017.12.002

Sawyer, L. and Habel, Y. (2014). Refracting African and Black diaspora through the Nordic region. African and Black Diaspora: An International Journal, 7(1), 1-6. https://doi.org/10.1080/17528631.2013.861235 
Shanklin, E. (1999). The Profession of the Color Blind: Sociocultural anthropology and Racism in the 21 st Century. American Anthropologist, 100(3), 669-679. https:// doi.org/10.1525/aa.1998.100.3.669

Simpson, A. (2007). On ethnographic refusal: indigeneity, 'voice' and colonial citizenship. Junctures: The Journal for Thematic Dialogue, (9), 67-80. https://junctures.org/index.php/junctures/article/download/66/60

Skeiv Ungdom \& Restart (2015). Riv Gjerdene. Et normkritisk metodemateriale i antidiskriminerende arbeid. Skeiv Ungdom. https://drive.google.com/file/d/1ziMkyjd0YbJ 2Rz9NqtyHb5B ZMNsKv4/view

Skadegård Thorsen, T. S. (2019). Minoritetsbeskatning - et værktøj til at forstå opretholdelse af strukturelle uligheder i dansk akademia. Kvinder, Kon \& Forskning, (1-2), 31-43. https://doi.org/10.7146/kkf.v28i1-2.116115

Smith C. A., Williams, E. L., Wadud, IA., Pirtle, W. N. L., The Cite Black Women Collective (2021). Cite Black Women: A Critical Praxis (A Statement). Feminist Anthropology 2(1), 10-17. https://doi.org/10.1002/fea2.12040

Smith, L. T. (1999). Decolonizing methodologies: Research and Indigenous Peoples. Zed Books.

Spade, D. (2006). Mutilating Gender. In Stryker, S and Whittle, S. (eds.), The Transgender Studies Reader. Routledge, pp. 315-332. https://doi.org/10.4324/9780203955055

Spade, D. (2015). Normal Life. Administrative Violence, Critical Trans Politics, and the Limits of Law (Revised and expanded ed.). Duke University Press. https://doi.org/10.1215/9780822374794 (Original work published 2011)

Spade, D. and Dector, H. (2016). Queer Dreams and Nonprofit Blues: Understanding the Nonprofit Industrial Complex [Video file]. S\&F Online, 13(2). https://bit.ly/2PNBu97

Stryker, S. (1994). My Words to Victor Frankenstein above the Village of Chamounix: Performing Transgender Rage. GLQ: A Journal of Lesbian and Gay Studies, 1(3), 237-254. https://doi.org/10.1215/10642684-1-3-237

TallBear, K. (2014). Standing with and speaking as faith: A feminist-indigenous approach to inquiry [Research note]', Journal of Research Practice, 10(2), Article N17. http://jrp.icaap.org/index.php/irp/article/view/405/371

Todd, Z. (2016). An Indigenous Feminist's take on the Ontological Turn: 'Ontology' is just another word for Colonialism. Journal of Historical Sociology, 29(1), 4-22. https://doi.org/10.1111/johs.12124

Towle, E. B. and Morgan, L. M. (2002). Romancing the Transgender Native: Rethinking the Use of the "Third Gender" Concept. GLQ, 8(4), 469-497. https://doi.org/10.1215/10642684-8-4-469

Trần, N. L. (2013, December 18). Calling IN: A Less Disposable Way of Holding Each Other Accountable. BGD. http://www.bgdblog.org/2013/12/calling-less-disposable-way-holding-accountable/

Tuck, E. and Yang, W. K. (2012). Decolonization is not a metaphor. Decolonization: Indigeneity, Education \& Society, $1(1), 1-40$.

Tuck, E. and Yang, W. K. (2014). R-Words: Refusing Research. In Paris, D. \& Winn, M. T. (eds.), Humanizing Research: Decolonizing Qualitative Inquiry with Youth and Communities. SAGE Publications. https://dx.doi.org/10.4135/9781544329611.n12 
Weiss, M. (2016). Always After: Desiring Queerness, Desiring Anthropology. Cultural Anthropology, 31(4), 627638. https://doi.org/10.14506/ca31.4.11

Wekker, G. (2016). White Innocence: Paradoxes of Colonialism and Race. Duke University Press. https://doi.org/10.1215/9780822374565

zeeninginlaos (2010). Working for you, me, us and them. What's the Non-Profit Industrial Complex and why should I care? [Zine]. https://bit.ly/3sYwtbV

\section{Links to student organisations}

African Student Association UiO https://www.instagram.com/asa uio/

Afro Student Association Trondheim https://www.facebook.com/ASATrondheim?locale=da DK

FRONT https://frontnu.wixsite.com/home

Saemien Studeenth Tråantesne https://www.facebook.com/studeenth/about/?ref=page internal

Sexology students against racism at Malmö University Soledad Quintana, Natalia Velasquez, Anette Grander och Karin Forsslund, https://www.sydsvenskan.se/2021-03-14/sexologer-hotas-med-disciplinara-atgarder-efter$\underline{\text { stormig }}$

SOCO (Students of Color Finland) https://www.ruskeattytot.fi/soco

Steatornis $\underline{\text { https://www.steatorn.is/en }}$

\section{Acknowledgments}

Oda-Kange's pronouns are she/her.

Nico's pronouns are they/them.

Disclosure Statement: No potential conflict of interest was reported by the authors. 